\title{
Arberry's Qur'anic Translation Pitfalls: Analysis, Implications
}

\author{
Mohammad A. Al-kuran ${ }^{1}$ \\ ${ }^{1}$ Yarmouk University, Jordan \\ Correspondence: Mohammad A. Al-kuran, Yarmouk University, Jordan. E-mail: mkuran9@gmail.com
}

Received: April 20, 2013 Accepted: May 23, 2013 Online Published: July 12, 2013

doi:10.5539/ells.v3n3p21 URL: http://dx.doi.org/10.5539/ells.v3n3p21

\begin{abstract}
Though Arberry's translation of the Qur'an into English is widely recognized as the best translation, it contains several inaccuracies that have minimized the significance of his work. Apparently, Arberry has not made such pitfalls deliberately to distort the intended message of the Qur'anic verses on a sectarian basis. His failures seem to derive from his lack of familiarity with the subtle meanings of some Qur'anic terminology and some cases of grammar including morphology and derivation, though he once served as professor of Arabic at Cambridge University. This paper intends therefore to highlight some of his failures in rendering the Qur'anic text into English in those respects and discuss their implications for the interpretation of the Qur'an.
\end{abstract}

Keywords: declension, faults, nuances, subtle, diacritics, derivation, etymology, plunge

\section{Introduction}

The orthodox Muslim view holds that the Qur'an cannot be translated, but can only be interpreted. For this reason, Arberry chose to call his rendition of the Qur'an into English an interpretation" rather than a "translation" on grounds that the translation might be equated with the word of God whereas interpretation is a human's words offered to explain the meaning of the Divine Revelation.

One basic criterion for interpreting the Qur'an's meaning and conveying it accurately to the target language is the translator's familiarity with the target language, which also involves his familiarity with its nuances. Mastery of the grammatical rules of Arabic, which is the primary focus of the present study, can help one get over potential interpretation problems. One should bear in mind when interpreting a book as great as the Qur'an that the classical rules of Arabic are highly founded on the Qur'an, and that grammar books and dictionaries were first made to protect against any potential future distortions against the Arabic language as a corollary of the expansion of the Islamic Caliphate. Most Arabic renowned dictionaries were not just mere records of word entries and their meanings. They had quotes from the Qur'anic interpretations and hadith of the Prophet, as well as commentaries of major Muslim scholars specialized in the interpretations of Qur'anic verses and the Islamic tradition such as Ibn Kathir and Attabari.

In a word, the great Arab dictionaries represent a great asset to consult when someone needs help in various braches of Grammar including morphology, declension, origins of verb roots and forms and their associated senses.

\section{Methodology}

This paper will discuss a number of pitfalls that Arberry had in interpreting the Qur'an. Examples of such faults are drawn from several chapters and highlight Arberry's occasional failures to grasp the nuances of the Arabic language. When the interpreter has acquired excellent knowledge of Arabic grammar, he becomes more capable of rendering the subtle shades of the Qur'anic terminology appropriately and hence eschewing confusions between Arabic words. This paper will not account for every pitfall Arberry had in his work. Rather, it will provide some illustrative examples of his misinterpretation to bring them to the light. This is not to slight the significance of his overall work, but to show that a message may be largely distorted because of failing to grasp a specific grammatical point.

As for the transliteration system, the author employs the International Romanization System (ISO 233) for the transliteration of Arabic characters. Its merit lies in applying stringent conversion principles that allows for international communication of the written message in such a way that gives access to automatic transmission and reconstitution. 


\section{Discussion}

\subsection{Signification of Diacritics and Derivation}

The term "diacritics" derives from the Greek word "diakritikos", to distinguish, to discern. In Arabic, a diacritic is an additional small sign added to the letter for pronunciation, grammar precision and accuracy. It is thus used in the Qur'anic texts to help the reader adhere to correct pronunciation and grasp the nuances of words correctly. To illustrate the point, let us take nouns as an example. Nouns in Arabic can be either definite or indefinite. Definite nouns are generally prefixed with the definite article $a l$, English "the". When a definite singular noun occurs in the object position, the ending sound of the noun is marked with fatha, a vowel sounding like English "a". When the indefinite singular noun occurs in the object position, the ending sound of the noun is marked with double fatha known as nunation. According to the declension rules of Arabic, finals of indefinite proper nouns, either in their object or genitive positions, are not marked with double fatha "nunation". Instead, they are marked only with a single fatha because they are diptotes. Thus, marking misr "Egypt" with a nunation violates basic Arabic grammatical rules, which stipulate that diptotes require only a single fatha in the genitive and accusative cases. By applying this rule to the following verse:

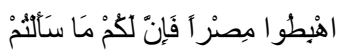

Ihbitū misran fa'inna lakum mā sa'altum [Qur'an 2:61], we find that Arberry's interpretation "Get you down to Egypt" is erroneous, simply because he disregards the fact that the ending sound of misran is marked with double fatha, which means that it is not denoting Egypt as a definite noun, rather, it denotes any inhabitant city. Thus, the reader should recognize the significance of such diacritical points in the Arabic language, which radically change the meaning of the entire text. Thus misran is not what is now Egypt as a country. Rather, it denotes any inhabitant city.

Lacking such kind of grammatical competence would lead to a false interpretation that Moses and his folk returned to Egypt after they had fled it and God saved them from Pharaoh and his men.

Knowledge of Arabic diacritics is so important for understanding the relation of one part of the sentence with another. Let us consider this verse:

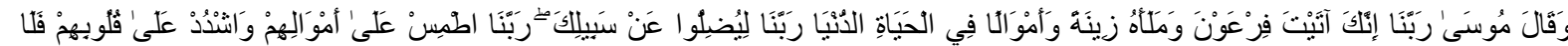

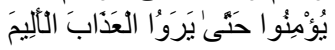

Arberry translates this verse thus: Moses said, 'Our Lord, Thou hast given to Pharaoh and his Council adornment and possessions in this present life. Our Lord, let them go astray from Thy way; Our Lord, obliterate their possessions, and harden their hearts so that they do not believe, till they see the painful chastisement.' [Qur'an $10: 88]$

The portion "Our Lord, let them go astray from Thy way" is rendered incorrectly due to Arberry failing to notice that the Arabic verb form vudillu is transitive, though not explicitly taking an obiect in this case. The root of the

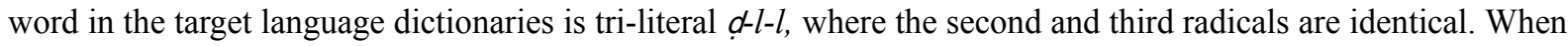
this root verb is used in prosody, it gets conjugated and therefore the second and third radicals are reduced to one geminated letter, with the middle unvowelled. Such geminated verbs contain doubled root consonants that can change word meaning and create meanings that are related, but not the same

The point is that the verb yadilu, he goes astray from the right path, and yudilu, causes someone to go astray, are two different verb measures signifying two different meanings. This difference has been overlooked, or put it differently, Arberry mistook the transitive yudilu for the intransitive yadilu.

In light of this explanation, Moses is not asking the Lord to let Pharaoh and his council go astray. Rather, He is critical of Pharaoh and his council for not having been thankful to their Lord for the grace he bestowed upon them. Instead of being thankful, they drove people away from the way of the Lord.

Other forms derived from the three -literal root verb $\underset{c}{-l-l} l$ are not easy for Arberry to grasp. For example, Arberry is mistaken in his rendition of the following Arabic verse, which addresses the Prophet:

وَوَجَدَكَكَ ضَنَالَ فَهَّى

wa wağadaka ḍallan fahadā [Qur'an 93:7], Did he not find you erring and guided thee? The word dalāl has actually multiple meanings that can be figured only by considering the contexts in which they are used. It expresses different types of people such as those misguided, unjust, misled by those whose business is to force others off the right path of God. None of these obscene descriptions applies to the Prophet. It is therefore erroneous to describe the Prophet as deviant from the right path: God witnessed that His messenger was faultless before and after the declaration of his prophet-hood. The assumption that the prophet was going astray from the 
God's light or was erring actually contradicts the sublime morality, which God has ascribed to his Prophet:

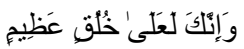

wa innaka la'ala huliqin 'adim, "you are of sublime morality" [Qur'an 68:4]

If we look up the word $\stackrel{d}{a}$ l, literally astray in Tăg ' \%'arūs dictionary, we would find that 'Al zubaidi (1965) lists several meanings under this entry, which diverge from its most common sense- astray, lost. $d \bar{a} l$ in the above dictionary denotes arms, pine like trees that grow in Yemen, darts, a mountain, the tip of a sword, an arrow and the like.

Al-Gortubi (1900) notes that the word $\frac{d a}{a}$ expresses a type of liking, love or tender attachment in particular contexts such as in:

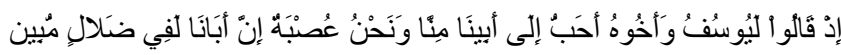

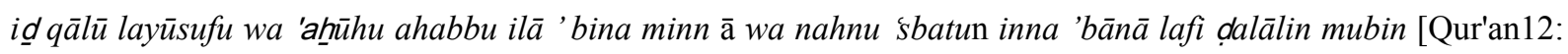
8]. This verse is mistranslated by Arberry as "when they said, "surely Joseph and his brother are dearer to our father than we, though we are a band. Surely our father is in manifest error". Arberry errs in this translation, probably because he is unaware that the Arabic word daläl is capable of multiple meanings, each of which is context- based.

It would even be ironic to think that Jacob, Joseph's father, is in a manifest error because he is particularly attached to one of his sons. Al-Qurtubi refers to daläl as a rather manifest devotion of Jacob to his son. Such implication of love is also cited in the Classical Arabic poetry: 'ğaban li 'zzä̈ fintityāri qatiati ba dal dalāli fahabluha qad anlafa, "I am struck at how zzata (his beloved) chose to cease her relation with me after having been in deep love .Lo! She did not keep her promise". Another example taken from the Arabic literature is: hä $\underline{\text { a }}$ ḍalālu 'șāba minni lmafriqa, "such love turned my hair white"

These examples show that daläl denotes not only misguidance or deviation from the true path of righteousness, but also a deep sense of love or devotion towards something or someone which Arberry failed to account for. The latter sense of daläl, "love "applies to the Prophet Mohammad who was engrossed in love of God, or, as an alternative interpretation, his people failed to appreciate his worth, so God guided them through him. This interpretation runs contrary to Arberry's interpretation, which does not hold much water as it is attributing erroneousness to the Prophet. Even the use of wağada, "to find", gives the impression that this verb was intended to be taken literally, as if God was looking for Mohammad and he finally found him to guide him. It is impossible to imagine how God can "find" when nothing in the universe acts like Him. It follows that Arberry should have refrained from using this word in its literal sense and, instead, opted for "knew" as an appropriate allegorical alternative for "found".

\subsection{Familiarity with Augmented Verbs Ad Root System}

The Arabic root system implies lexical meaning because it communicates a general semantic field within which an actual lexical item can be located. However, there are verbs that fall within the same semantic field, but are not the same, though they may look alike. Arberry for example fails to notice the subtle difference in meaning of verbs derived from the same radical root letters. Let us consider this verse concerning Gog and Magog:

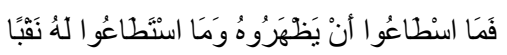

fama stā̄u 'an yadharūhu wamastatāū lahū naqba [Qur'an 18: 97]. Arberry interprets it thus "So Gog and Magog were unable either to scale it or pierce it". This rendition indicates that ascending and digging through the wall are of equal difficulty for Gog and Magog. This rendition does not capture the subtle difference in meaning as reflected in the Qur'anic verse. He probably assumes that the two words are semantically related as equal. According to the rules of Classical language, any increase of letters in the word suggests more in meaning. Thus, istatā $\bar{u}$ conveys more meaning than istā $\bar{u}$ because the former is more augmented: there are more letters prefixed to istatāu than to istā $\bar{u}$. The implication of such augmentation in form suggests that digging through the wall is more difficult than ascending it, a difference not accounted for by Arberry.

Such a failure to realize the difference between these two words will bring about an interpretation that mismatches the translations of the great authoritative interpretation sources such as Ibn Kathir (2001) who asserts that the intensity of the verbal form reflects the intensity of the action, which has to do with the subtleties of meaning. Thus, although the two words are derived from the tri-literal root tawa'a, "to accord with", "be manageable", as indicated in Lisān 'al Arab by Ibn Manzur (1999), they still diverge in meaning to some extent.

Such a failure to capture the intensity of the action is also evident in this verse: 


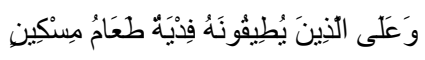

wa 'alalla dina yutiūkūnahū fidyatun tá ämu miskin [Qur'an 2: 184]

Arberry renders it thus: "And for those who are able to fast, a redemption by feeding a poor man". This rendition is actually contrary to the true meaning implied by the verb yutiqunahu in the original. According to Hans Wehr (1974), tawaqa is to put a collar or a ring around someone's neck, to enclose. In light of this root meaning, when fasting is felt like a collar tightened a round someone's neck, a person is authorized to break the fast and should accordinmgly redeem it by feeding a poor man.

Likewise Almāwardi (1992) contends that the verb refers to those who can barely fast on account of sickness, nursing and old age because fasting under such conditions is life-threatening. Thus the derived verbal noun itāqah, does not denote just a mere ability, but something hardly affordable. Almāwardi notes that yutiqūnahu refers to those obliged to fast, but cannot afford it or are strained by the fast. This indicates that fasting is not an option to be dispensed with, but an obligation that is prescribed for those who believe. Put differently, Almāwardi deems the feeding of a poor man in lieu of the fast as a license for people to break their fast when they experience an unbearable condition. This meaning contradicts that of Arberry's which shows that any person that is able to fast, has to redeem a poor man by feeding him.

Undoubtedly, Arberry failed to notice the subtle shades of meanings rendered by the Arabic words yutiqūn, istā̄ and istat $\bar{a} \bar{u}$. He treats these three verbs as if denoting one English word "ability", without revealing the varying degrees of difficulty that they imply. One would detect the subtle difference between the first two words if he consulted Arabic root system and implications of augmentation of such verbs in great Arab dictionaries on which great scholars had relied.

In a similar vein, Arberry would not have been at fault in relation to the interpretation of yutiqūn had he consulted the great exhaustive reference Lisān 'al 'arab, which provides a great deal of information on all the roots and all the words derived from those roots, which had been in use, together with ample illustrative examples. At times, the word is capable of multiple meanings, and only the context can help determine the intended meaning.

\subsection{Pronoun Reference}

At times, Arberry fails to match nouns and their corresponding pronouns in some Qur'anic verses thereby distorting the message conveyed. Let us consider these verses:

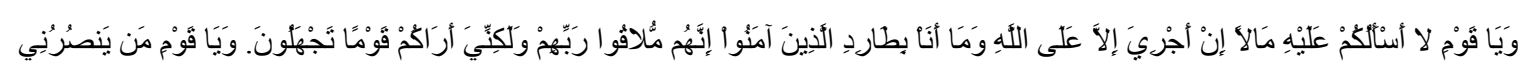

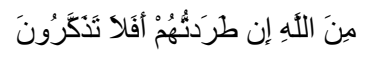

yā qawmi la 'as'lukum 'laihi mālan in 'ğriya illa 'la allah wamā 'na bitaridi lladina āmanu innahum mulāqū rabbihim , lākinni 'rākum qawman tağhalūn, waya qawmi man yansuruni mina allāh in țaradtuhum 'falā tadakkarūn

"O my people, I do not ask of you wealth for this; my wage falls only upon God. I will not drive away those who believe; they shall surely meet their Lord. But I see you are an ignorant people. O, my people. who would help me against God, if I drive you away?" [Qur'an 11:30]

Like many other languages, a transitive Arabic verb requires a pronoun object to replace and refer to its noun object. The pronoun object hum, "them" in taradtuhum, refers back to its object noun alladina āmanu, those who believe, and not to the addressees, folk of the Prophet Noah, who do not believe. Thus the prophet here fears God's punishment if he drives away those who believe, and not his people who opposed his call.

Arberry mistook taradtuhim, "drive them away" for taradtukum, "drive you away" which certainly skews the meaning of the verse and communicates a wrong message. The pronoun object on the verb must agree with the noun it refers to both in gender and number.

Another evidence of failing to notice the connection between the antecedent and the pronoun referring back to it is obvious in:

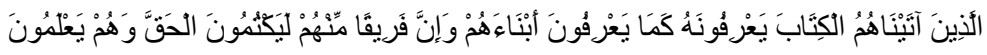

'lladina ātaināhum lkitāba y'rifūnahu kama y'rifūna 'bnā'ahum wa inna fariqan minhum layaktumūna alhaqqa wahum y'lamūn

Those to whom We have given the Book recognize it as they recognize their sons. Those who have lost their own 
souls, they do not believe. [Qur'an 6:20]

Arberry assumes here that the pronoun attached to y'arifūn, "they recognize", refers back to al kitaab, "the book", which is not the case. The antecedent is not the book, but Prophet Mohammad. Actually great Muslim scholars all agree that the attached pronoun refers to the Prophecy of Mohammad in the Old Testament and the Bible. Perhaps what prompted Arberry to consider the book the antecedent of the suffixed pronoun ya'rifunahu is that it occurs right before the pronoun. There are cases, however, where the pronoun refers to an antecedent mentioned earlier in a separate verse or discourse. In this case, one should consider the previous verse, which in this case reads:

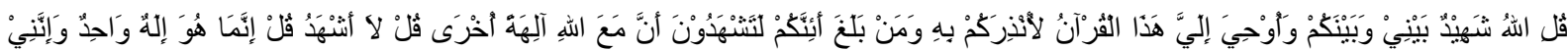

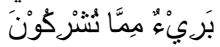

Qulillāhu šahidun baini wa bainakum wa ūhiya ilaiyya hā a alkurān li un erakum bih waman balaga 'innakum latašhadūna 'nna m'a allāhi āliha unhra qul innamā huwa allāhu wāhidun wa innani bari'un mimmā tušrikūn

Say: 'God is witness between me and you, and this Koran has been revealed to me that I may warn you thereby, and whomsoever it may reach. Do you indeed testify that there are other gods with God?' Say: 'I do not testify.' Say: 'He is only One God, and I am quit of that you associate.' [Qur'an 6:19]

In the foregoing discourse, God summons Prophet Mohammad to testify that there is only one God and that is witness between him and the disbelievers. The point here concerns Mohammad to whom the prefixed pronoun in Ya'rifun refers back, though almost all non-Muslim theories about Mohammad in the Christian bible are nothing more than conjectures.

Again, Arberry is mistaken about creating an object pronoun that refers back to a wrong mistakable noun antecedent. Let us consider this verse:

إنما وليكم الله ورسوله و الذين آمنوا الذين يقيمون الصلاة ويؤتون الزكاة و هم ر اكعون

innamā waliyyukum llāhu warasūluhu walladina āmanu alladina yuqimūna ssalāta wayu'tūna zzakāta wahum rākiūn

Your friend is only God, and His Messenger, and the believers who perform the prayer and pay the alms, and bow them down. [Qur'an 5:55]

There is no point to create a pronoun object "them" for the proposed noun antecedent, "alms" since it does not correlate with the original target text, which shows that those who believe perform the prayer and give Zakat when they kneel during the prayer. In other words, it makes no sense to have alms and prayers bowed down.

There is also the case that Arberry fails to identify the pronoun reference when it shifts in the same verse from one addressee to another. Let us consider the following verse:

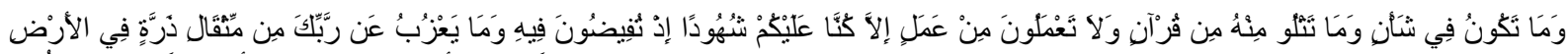

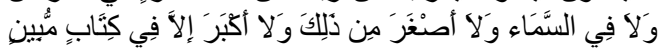

"Thou art not upon any occupation, neither recitest thou any Koran of it, nor do you"

any work, without that We are witnesses over you when you press on it; and not so much as the weight of an ant in earth or heaven escapes from thy Lord, neither is aught smaller than that, or greater, but in a Manifest Book. (Qur'an 10: 61)

Unlike in English, in Arabic the pronoun "you" marks singular and plural with distinction. In almost every case where pronoun "you" is used in the singular, the addressee being the Prophet. In the above verse "you" is used three times in the plural. The English translation, however, does not show that difference because in English "you' marks both singular and plural without distinction. Therefore, to make the English translation correlate with the Arabic original, Arberry should have added the word "Prophet" to the English version where "you" is used in the singular so that the reader would not miss that it is the Prophet who is being addressed. The English translation should read thus:

Thou art [Prophet] not upon any occupation, neither recitest thou [Prophet] any Koran of it, nor do you [plural, referring to the whole community] any work, without that We are witnesses over you[ plural] when you [plural] press on it; and not so much as the weight of an ant in earth or heaven escapes from thy [Prophet] Lord, neither is aught smaller than that, or greater, but in a Manifest Book. (Qur'an10: 61)

\subsection{Word-Associated Meanings}

There are cases where the literal meaning seems untrue or does not make sense. The use of the allegorical 
language makes the description more powerful since it takes the word beyond its defined or normal meaning. Great Arabic dictionaries make use of so many words along with their derivations and applications in various contexts. It takes effort and time to scrutinize all possible associations of a given Qur'anic item to render it accurately by drawing upon the subtle shades associated with it. It should be noted that meanings are not always consistent regardless of their contexts.

Arberry, for example, errs when he takes the Arabic word hauwd, "plunge", in its literal sense in this verse:

الآذِينَ هُمْ فِي خَوْضِ يَلَعَبُونَ

'a lladina hum fi hawdin yal ábūn [Qur'an 52:12], which he translates thus "such as play at plunging". Though terse, this translation is inaccurate. If the word 'plunge" is looked up in the Oxford Advanced Learners Dictionary of Current English, one can find entries such as "go suddenly and with force", "gamble deeply", "run into debt", "move forward and downward quickly". These entries do not seem to capture the intended meaning of the original in the context of the Qur'an. If we check this word in an Arabic-English dictionary, we may encounter otherwise entries. For example, in his Arabic-English dictionary, Hans Wehr (1974) defines haw "discussion", "treatment of a subject", "become obsessed or engrossed in", "to go into a subject". This is also reflected in Lisān 'Al Arab by Ibn manzur (1999), who takes haaw d as indulgence in blasphemous or idle talk concerning God's revelations and Prophet-hood of His Messenger. Therefore, the kind of haw points to the vain talk or discussion with which the blasphemous are busily engaged. This is actually the sense in which the word is used in the Qur'an. There are of course other meanings associated with haw $d$ in various Arabic dictionaries, but have been ignored because they do not serve our purpose in this regard.

There is no escape, however, from admitting that the multiple meanings of a word can lead to confusion and misinterpretation when the translator is unaware of the possible range of meanings associated with the word in question. For example, the Arabic word jabal, literally "mountain" has other meanings that Arberry is apparently not acquainted with. This word indicates different things in different contexts, and hence takes on multiple connotations- grandeur, power and abundance of the thing. Mustafa, Zayyaat, Abdel qader, \& Annajjar (1989) refer to some of these significations in 'Alma 'ğam 'alwasit dictionary such as nation, a group of people, space, huge mass, and chieftain. Arberry, however, renders ğabal in accord with its literal denotation in this verse:

وينزل من السماء من جبال فيها من برد فيصيب به من يثاء ويصرفه عن من يثاء

wa yunazzilu mina ssamā min ğibālin fihā min barad fayusību bihā mayyašă ' wa yasrifuhū 'mman yaš ă' [Qur'an 24:43], "And He sends down out of heaven mountains, wherein is hail, so that he smites whom he will with it; and turns it aside fro $\mathrm{m}$ whom he will".

It is obvious that Arberry's interpretation of ğibāl as "mountains" in this context does not capture the allegorical sense that is intended in the use of ğibāl (plural of ğabal). In fact, ğibāl is used here in its allegorical sense where clouds are driven then heaped into masses out of which rains are issued. The heaped masses of clouds are thus intended to denote ğibāl.

\subsection{Rhetorical Questions}

Different words may suggest the same meaning if the translator is unaware of the subtle shades of the competing meanings of these words. The two Arabic interrogative words 'yyāna and matā, "when", are not quite semantically equal when considered in the Qur'anic discourse. Arberry takes both interrogative words as semantically equal without elaboration for the clarification of the subtle difference between them. They are rendered alike into the English "when". Let us consider these two verses:

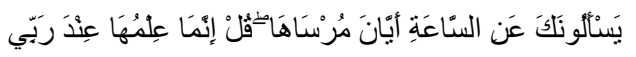

yas'l ūnaka ín issā ati 'ayyāna marsāha Qul innamā ilmuhā inda rabbi lā yuğallihā liwaqtihā illā huwa [Qur'an 7:187]. Arberry translates this verse thus: "They will question you concerning the Hour, when it shall berth. Say: "the knowledge of it is only with my Lord; none shall reveal it at its proper time, but he"; and yas'alüna ayyāna yawmu ddin [Qur'an 51:11] they ask: when will the day of resurrection be"

The word 'yyāna is comprised of 'yy, a mere interrogative particle, and $\bar{a} n$ or 'wān denoting time. This interrogative particle inquires about a possible particular point in the future at which the Hour or the day of the doom will occur. According to Alğalälain (1995), the question is asked by the disbelievers derisively to mock those who believe in the Hour or the day of the resurrection. The question therefore implies a denial that the day of the doom will ever take place. This implication was not captured in Arberry's interpretation.

In a similar vein, Arberry fails to elaborate a bit to capture the meaning of matā in this verse: wa yaqūlūna mata hādal wa'du in kuntum sādiqin \{Qur'an 67: 25), "They say: when will this promise come to pass if you speak 
truly? Again "they" here refers to the disbelievers who deny the occurrence of the chastisement in the day of the doom.

Although this interrogative particle occurs several times in the Glorious Qur'an, it does not ask about a particular future point of time. In other words, it is not asking about the exact date of the Hour or day of the doom, as 'yyāna implies. There is not even one verse in the Glorious Qur'an that reads yas'lüna matā yawmuddin, "They ask: when will the day of the doom come to pass" because matā is not signifying a specific day or Hour that triggers the resurrection. Put differently, matā is used in a more generic sense. That is, it seems inappropriate to substitute it for ayyaana-yas'lūna matā yawmuddin instead of yas'lüna 'yyana yawmuddin.

In his book, Mafätih 'lgaib, 'rrazi $(1981,2004)$ notes that the two interrogative particles imply derision because the disbelievers ask about the hereafter out of their disbelief in it. Yet, Arrazi asserts that 'yyāna implies not only that the thing in question will never occur, but also the disbelievers want it to take place soon were it true. According to Arrazi, the disbelievers are cynical about the Hour [hereafter], which is called so because it will occur all of a sudden, and people will then be atoned in just an hour. Whereas mata implies that they ask about the hereafter without any specific reference to the day on which such event will happen, it does not imply that they want it to occur soon.

\section{Implications for Qur'anic Interpretations}

Although Arberry has been praised for providing the best English version of the Qur'an, there are pitfalls in his work that might slight its significance. The pitfalls presented earlier represent some of Arberry's linguistic deficiencies in Arabic. Areas as diverse as derivation, declension, and pronoun reference have a great effect on understanding the message of a Qur'anic text, and thus are of utmost significance in grasping the Glorious Qur'an. Derivation helps one grasp meaning and discerns the application of a meaning in every linguistic form that signifies the meaning. It will provide one's knowledge of language with rich resources because it assists in elucidating the way the Arabic root system works and thus shows the meaning of a word from different angles.

Of equal importance is that lack of familiarity with Arabic diacritics leads to syntactic errors, which cause the reader to misinterpret the message since these small markings appearing above and below letters actively govern meanings of words.

Also important in grasping the message is identifying correctly the proper reference of pronouns since they shift even in the same verse with the risk of ambiguity and skewing of meaning

These branches of knowledge, which may represent various aspects of grammar can disambiguate meanings of Arabic terms and therefore brings about accurate translations in line with the meanings expressed in great Arabic dictionaries, which provide not only mere lists of word entries along with their primary senses, but a repertoire of Muslim exegetes as well

\section{References}

'Al Masri, Ibn Manzur. (1999). Lisān 'Al Aarab (Vol. 13). Beirut: Dār 'ihyā' 'atturāt 'Al'arabi.

'Al Qurtubi, M. (1900). 'Alğāmi 'li'ahkām 'al-Qur'ān. Tehran: 'Almaktabah al'ilmiyya.

'Almāwardi, A. (1992). 'Annukāt wal uyūn (Vol. 1). Beirut: Dār 'Alkutub 'Al'ilmiyyah.

'Alzubaidi, M. (1965). Tāğ 'al 'arūs (Vol. 15). Beirut: Dār 'Al hayāt.

'Arrazi. A. (1981). Mafātih 'algaib (Vol. 29). Beirut: Dār 'Al fikr Littibā̄ä̈ Wannašr.

'Arrazi. A. (2004). Mafātih 'algaib (Vols. 15-16). Beirut: Dār 'Al kutub 'Al ilmiyya.

'Assuyūti, J., \& 'Al mahalli. J. (1995). Tafsir 'alğalālain (1st ed.). Beirut: Mu'assasä̈ 'Arrisālah.

'Attabari. M. (1972). Tafsir 'al Qur'ān (Vol. 16). Cairo: Dār 'Al-mª̄rif.

Hans Wehr. (1974). A Dictionary of modern written Arabic. Beirut: Maktabä̈ Lubnan.

http://www.filesin.com/B7E3960060/download.html

Ibn Katir. M. (2001). Tafsir 'al-Qur'ān 'al 'adhim (Vol. 1). Riyadh: Maktabä̈ 'Arrašid.

Mustafa, I., et al. (1989). 'Alma ğam 'al wasit. Beirut: Mağam 'a llugä̈ Al-'arabiyya.

\section{Copyrights}

Copyright for this article is retained by the author(s), with first publication rights granted to the journal.

This is an open-access article distributed under the terms and conditions of the Creative Commons Attribution license (http://creativecommons.org/licenses/by/3.0/). 